\title{
Anti-desertification Legislation and Ecological Problems in Xinjiang China
}

\author{
Nurongguli Tuoheti ${ }^{1}$, Maimaitiaili Abulaiti ${ }^{2}$, Zafar Ahmed $^{3}$ \& Namaitijiang Maimaiti ${ }^{4}$ \\ ${ }^{1}$ Law School of Xinjiang University, China \\ ${ }^{2}$ Faculty of law, International Islamic University Malaysia, Malaysia \\ ${ }^{3}$ ITCC, UKMMC \\ ${ }^{4}$ United Nations Universities-International Institute for Global Health \\ Correspondence: Nurongguli Tuoheti, Law school, Xinjiang University, South campuses, No1230 Yanan Road, \\ Urumqi City, Xinjiang, China. Tel: 86-1-360-991-2941. E-mail: nurumgul@yahoo.com.cn
}

Received: July 12, 2013 Accepted: July 19, 2013 Online Published: August 30, 2013

doi:10.5539/jpl.v6n3p160 URL: http://dx.doi.org/10.5539/jpl.v6n3p160

\begin{abstract}
Desertification (transformation of arable or habitable land to desert) is one of the serious environmental problems and has attracted worldwide attenntion. Apart from its threat on the living environment, desertification has also been an obstacle to social stability and global economy. China the oldest continuous major world civilization, a population of more than 1.3 billion and a territory of 9.6 million $\mathrm{km}^{2}$, is one of the most severely desertified countries in the world. Desertification is especially severe in Xinjiang Uyghur autonomous region of China. However, the legislation,enforcement and jurisdiction of law in terms of anti-desertification in Xinjiang is seriously flawed, as a result of planned economy and are not consistent with the market economy. Aim of this study is to evaluate the desetification problem in Xinjiang, and analyze the problem of desertification from the perspective of law. This research starts with the investigation of desertification in Xinjiang with reference to legislation and enforcement of law in terms of desertification in other countries. Legislation analysis with regard to the anti-desertification legislation of Xinjiang are discussed. There is no clear delineation of responsibility between administrative and other departments in the current anti-desertification reginal law system in Xinjinag. Reginal legislation lacks systematic protection. The main body of resource management is not clearly defined and regulations concerning financal support are not reasonable. The anti-desertification in Xinjiang lack of support in terms of ecological protection.
\end{abstract}

Keywords: Xinjiang, eco-environment, desertification, legislation, problem, counter-measure, law, policy

\section{Introduction}

\subsection{Introduction of Problem}

Sustainable development concept blends the man and environment based on the equity of the new ethical values and ethics, governed by the ecological law and morality (William Leiss, 1993). The concept of sustainable development is violated by the accelerated degradation of the environment. Desertification is one such example. Desertification (transformation of arable or habitable land to desert) is one of the serious environmental problems and has attracted worldwide attention. Apart from its threat on the living environment, desertification has also been an obstacle to social stability and global economy. Proper legislation should be in place to manage this menace of desertification. Anti-Desertification Legislation has its base from environmental law. Its main purpose is to protect social values in the statute made on the performance and response and deals with the development and implementation of laws, legal interpretation and application of the guiding principles and theoretical basis that govern this legislation.

The ultimate purpose of anti-desertification environmental legislation should be based on the values of sustainable development, achieving a harmonious development between man and nature, and protect human and ecological interests (Shi Yucheng, 2005). With a territory of $9 \cdot 6$ million $\mathrm{km}^{2}$, China is one of the most severely desertified countries in the world. Desertification is threatening the lives of close to 400 million people and has affected about 3.3 million $\mathrm{km}^{2}$ of land (Kram et al, 2012). 
Desertification is caused by a combination of factors that change over time and vary by location. These include indirect factors such as population pressure, socioeconomic and policy factors, and international trade as well as direct factors such as land use patterns and practices and climate-related processes resulting in the unsustainable use of scarce natural resources. This may lead to decreased land productivity and a downward spiral of worsening land degradation and poverty. Recurrent dust storms, now a day, have emerged as one of the most critical concerns arising from the manmade ecological imbalance in China. The frequent occurrence of dust storms has been attributed to both deforestation and the changing environment in the areas adjacent to Gobi desert system like Xinjiang autonomous region (Menon et al, 2002). Desertification phenomena in Xinjiang not only restrict the sustainable development in Xingjiang, but affects entire China and the geographical areas connected to China. For e.g. the dust storms in March 2003, not only affected Xinjiang, but also affected Beijing, Tokyo, New York and other major cities in the world. Therefore, desertification should be considered a global environmental problem, even though the origin is local, and hence the control of the expansion of desertification, should be a strategic goal in the current strategy for achieving global sustainable development in China. Strict enforcement of law may control the desertification and the side effects of the ecological and environment degradation in Xinjiang.

Desertification is mainly caused by human activities in Xinjiang. If the human activities are within limits the environment will have time to recover from the manmade destruction of nature and the ecosystem is sustained. But once the human activities are beyond the self-sustainability of the natural environment, coupled with the adjacent desert areas, the environment would be severely degraded.

Desertification can exacerbates the poverty of people in Xinjiang that in turn leads to more deforestation, leading to regional disparities that may not be very conducive to national prosperity, national unity and social stability.

Therefore the administrative systems, systems that protect the environment and prevent deforestation, supported by an effective legislative system can break this vicious cycle. This is a complex triad of natural resources, administrative system protecting these natural resources, and the supporting legislative system that not only affects the speed and quality of economic development but also guide people's behaviour. Therefore, we must study the causes of desertification in Xinjiang and must not ignore the implementation of administrative systems and their impact of desertification in Xinjiang. Aim of this study is to evaluate the desertification problem in Xinjiang, and analyse the problem of desertification from the perspective of law.

\section{Method}

\subsection{Study Design}

This review study is based on available information on ecological value of anti-desertification in Xinjiang and content analysis of environmental legislation and desertification problems and the ecological environment of judicial practice in Xinjiang. This study explains the desertification problem in the Xinjiang Uyghur autonomous region of China and review the anti-desertification legislation available in this area. This study starts with the investigation of desertification in Xinjiang with reference to legislation and enforcement of law in terms of desertification in other countries. Legislation analysis with regard to the anti-desertification legislation of Xinjiang is discussed.

\subsection{Study Location}

The study was conducted in Xinjiang Uyghur Autonomous Region of the People's Republic of China. Xinjiang is in the North-Western part of China and is a large, sparsely populated area (spanning over 1.6 million sq. km) which takes up about one-sixth of the country's territory. Xinjiang borders the Tibet Autonomous Region to the south and Qinghai and Gansu provinces to the southeast, Mongolia to the east, Russia to the north, and Kazakhstan, Kyrgyzstan, Tajikistan, Afghanistan, Pakistan and India to the west (Xinhua net). The Taklamakan Desert, also known as Taklimakan and Teklimakan, is a desert in the southwest portion of the Xinjiang Uyghur Autonomous Region in northwest China. It is bounded by the Kunlun Mountains to the south, the desert Pamir Mountains and Tagritagh (Tian Shan) to the west and north, and the Gobi Desert to the east. The Taklamakan Desert has an area of 337,000 km2 (130, 116 sq. mi.) (Jimin Sun and Tungsten Lou, 2006), and includes the Tarim Basin, which is 1,000 kilometres $(620 \mathrm{mi})$ long and 400 kilometres $(250 \mathrm{mi})$ wide. It is crossed at its northern and at its southern edge by two branches of the Silk Road as travellers sought to avoid the arid wasteland (Ban, Paul G). It is the world's second largest shifting sand desert with about $85 \%$ made up of shifting sand dunes (Taklamakan Desert, 2007) ranking 18th in size in a ranking of the world's largest non-polar deserts (The World's Largest Desert, 2007). 


\section{Result}

Based on history it can be noticed that the formation of the desert in Xinjiang is mainly due to natural factors, but the occurrence of modern desertification is not only due to external factors but it also involves internal factors as well. The population's inappropriate and excessive use of natural resources due to rapid social and economic development activities being the main internal factors contribution to desertification this is shown in figure 1.

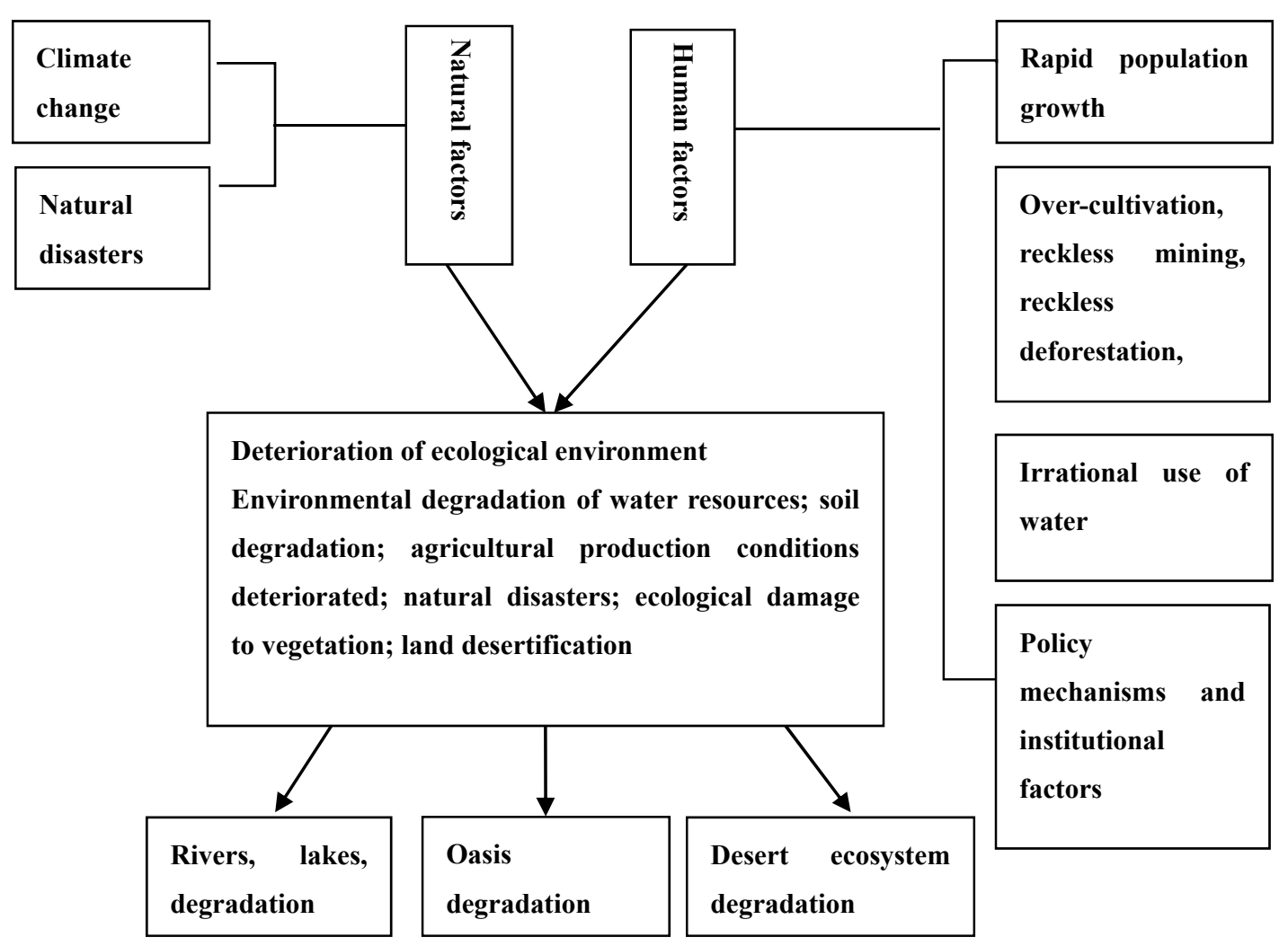

Source: Liu Xin Ping and Han Tong kui, 2005

Figure 1. Oasis and the causes of ecological degradation

In Xinjiang the dominant factor in the deterioration of the fragile ecological environment and the desertification of land is the population's unchecked exploitation of the natural resources under the guise of socio-economic development. That has leads to the unreasonable use of the land and management of the natural resources and potentially resulted in the vulnerability of the natural environment and real damages. Desertification has exacerbate the poverty of people in Xinjiang that in turn leads to more deforestation, leading to regional disparities that may not be very conducive to national prosperity, national unity and social stability.

Legislation to combat desertification in Xinjiang is usually a wide range of motives, including the legal system planning factors, but also non- planning factors. Such as system integrity, requirements of the system around the impact of the crisis out, political ideals and mission statement, the public's petitions and so may contribute to the formulation of laws and regulations (Wang Jin, 2000). Therefore, overlapping legislation is the result of multiple factors. The purpose of the Act refers to legislators to make laws is seeking through the performance, implementation of certain social relations, legal regulation of motives and intentions of the starting point. The formulation of a law, the first condition should be given the fact that the laws of the legislator's intention and motivation, that is consistent with legislative intent (Zhou, 2003).

The legal system concerning the environmental protection in Xinjiang is not very strong and there is a structural lack of coordination. For example; currently there are dozens of sand prevention and control of natural resources 
legislation, regulations, and government orders in Xinjiang. The Environmental Protection Basic Law has structural deficits regarding important issues and the special regulations omissions and that has created a lack of unification in the environmental protection process. The existing environmental laws and regulations in Xinjiang, often protect only the resources under the Act, without or little regard to the other environmental factors in general. Therefore with no proper measures protecting the environment, it is difficult to combat land desertification and ecological damage. For e.g.; according to statute "Desertification of certain provisions of Xinjiang Uygur Autonomous Region," Article VIII: Huge amount of sand during mining, oil exploration, road building and other development and construction activities may harm the environment. The construction unit (Developing Company / Developers) shall submit its anti-desertification program master copy of the environmental impact report to local forestry department. Development units (Developing company/ Developers) should follow the principle of "who exploit, who protects, who control" , and make sure that the development zone sand and desertification funds are included in the project budget. In the case of land usage for construction, heavy financial compensation is made for the land acquisition, and usually minimal resources are allocated for the protection of ecological environment. On the other hand, for agricultural land, the rentals are paid without any provision for the resources for protection against over-grazing. The over-grazing phenomena may occur in this case and may lead to grassland degradation, leading to desertification.

Xinjiang region also has the history of management of a single resource by several different departments, and that has resulted in the Co-existence of several laws for the protection and utilization of the same resources. Due to this lack of necessary regulatory coordination between the different departments for management of a resource, the corresponding resources cannot be effectively protected and managed. Currently the local legislation in Xinjiang is to ensure proper action in case of any environmental degradation or any harm to human life. Whenever there is a need the local Xingjiang legislation is also supported by a process to improve current legislation or take aid from the national legislation to supplement the local legislation.

The legislative motives are often in unity with primary focus on the promotion of economic development and protection of human health, and there is very little consideration of environmental protection and ecological damage compensation. Therefore it is safe to say that between the economic interests and environmental trade-offs, the economic benefits always take precedence over the environmental protection (Zhang li, 2004).

That makes the Anti-desertification legislative system imperfect in Xinjiang. Anti-desertification and environmental resource protection includes a number of important legal systems, such as property system, management of natural resources, ecological compensation mechanism, the pricing mechanism of natural resources, environment protection etc. In the existing system it is difficult to formulate the laws and regulations regarding the environmental protection. Public participation to the formulation of legislation is weak, public also do not attach importance to the development of civil society and the role of environmental organizations. Public is also wary of the government control, public participation, establishing the social checks and balances and developing a combination of law enforcement mechanisms for environmental protection. There also exist some very controversial legislations, such as "Land Management Regulations" that explains the "balance of arable land", and requires the area of the occupied land should be added to the area of arable land. In this case, the land is usually used as a supplement "available" (but not used) for the agricultural land."

The "anti-desertification law "article thirty two state, "The State Council, District and local governments at all levels, in accordance with the planning of desert prevention budget, allocate funds for people's governments Desertification control projects. The poverty alleviation, agriculture, irrigation, roads, energy, and agricultural development projects should be established according to the anti-desertification requirements".

We can see from the table 1 below, the sources of current investment funds for desert prevention and transformation mainly comes from government funding. The investment benefits are poor, and sometime the funds are being wasted. The current desert prevention investment legislation has not been established based on principles of market economy. For e.g. Xinjiang invests large amount of funds, use manpower for forestation, but most areas only do plantation without any regard for what they grow, with resultant forestation end almost fruitless, and therefore the funds for desert prevention and transformation cannot effectively play its due role.

As the ecological environment in Xinjiang area involve many industries and sectors, the environmental protection department of Xinjiang has unified the environmental supervision and other relevant departments responsible for the management and implementation of environmental protection legislations in Xinjiang. In accordance with national anti-desertification and environmental law and Xinjiang local laws and regulations the administrative functions of agencies related to the environment are generally divided into two categories: One is the government environmental protection administrative department of Xinjiang (autonomous regions and EPA) 
on the implementation of a unified environmental supervision and management; and the second is the State Council, other relevant administrative authorities, within their respective mandates for environmental protection in the implementation of the division responsible for the supervision and management, such as local grassroots Forestry, Water Conservancy Bureau, Land and so on. They are jointly responsible for the regional government.

Table 1. Environmental protection policy and anti-desertification in Xinjiang construction engineering

\begin{tabular}{|c|c|c|c|c|}
\hline Category & Project Name & $\begin{array}{l}\text { Organization and } \\
\text { Investment } \\
\text { Institution }\end{array}$ & $\begin{array}{l}\text { Duration } \\
\text { Scale }\end{array}$ & Substance \\
\hline Policy & $\begin{array}{l}\text { State-owned barren } \\
\text { hills and wasteland, } \\
\text { wasteland and } \\
\text { ecological forests } \\
\text { and pastures. }\end{array}$ & $\begin{array}{ll}\text { Xinjiang } & \text { Local } \\
\text { Government. } & \end{array}$ & Xinjiang & $\begin{array}{l}\text { Land use rights for } 50 \\
\text { years, exemption from } \\
\text { land transfer (XJ, 2003) }\end{array}$ \\
\hline Plan & $\begin{array}{l}\text { Ecological } \\
\text { Environment } \\
\text { Construction Plan }\end{array}$ & Xinjiang Corps & Xinjiang 174 Farm & $\begin{array}{l}\text { Organization } \\
\text { implementation }\end{array}$ \\
\hline Project & $\begin{array}{l}\text { Comprehensive } \\
\text { improvement of } \\
\text { ecological } \\
\text { environment of the } \\
\text { Tarim project }\end{array}$ & $\begin{array}{l}\text { Central } \\
\text { Government }\end{array}$ & $\begin{array}{l}\text { 2001-2005 } \\
\text { 10.7 Billion }\end{array}$ & $\begin{array}{l}\text { Construction of water } \\
\text { projects shelter (XJ 2003) }\end{array}$ \\
\hline Policy & $\begin{array}{l}\text { Grassland } \\
\text { construction }\end{array}$ & $\begin{array}{l}\text { Xinjiang Local } \\
\text { Government }\end{array}$ & $\begin{array}{l}\text { 6.5 Billion in } \\
2003-2010\end{array}$ & $\begin{array}{l}\text { 5.7ha irrigated grassland } \\
\text { eco-construction } \\
\text { resettlement }(\mathrm{XJ}, 2003)\end{array}$ \\
\hline Project & $\begin{array}{l}\text { Tarim Desert } \\
\text { Highway shelterbelt } \\
\text { ecological } \\
\text { engineering }\end{array}$ & $\begin{array}{lr}\text { State } & \text { Reform } \\
\text { Committee and } \\
\text { China National } \\
\text { Petroleum } \\
\text { Corporation. }\end{array}$ & 220 million yuan & $\begin{array}{l}3 \text { years, } 436 \mathrm{~km} \text { shelter } \\
\text { (XJ 2003). }\end{array}$ \\
\hline Plan & $\begin{array}{l}\text { Wada Ecological } \\
\text { Construction } \\
\text { Planning }\end{array}$ & $\begin{array}{l}\text { State Council } \\
\text { Officially } \\
\text { Approved } \\
\text { Implementation. }\end{array}$ & $\begin{array}{l}\text { Total investment of } \\
1.3 \text { billion }\end{array}$ & $\begin{array}{l}\text { Plantation } 65,000 \text { ha, } \\
\begin{array}{l}\text { Forestation and grass } \\
18.35(X J, 2003)\end{array}\end{array}$ \\
\hline Project & $\begin{array}{l}\text { Pastoral grassland } \\
\text { ecological } \\
\text { protection, water } \\
\text { security } \\
\text { construction } \\
\text { projects }\end{array}$ & Country & $\begin{array}{l}2003-2010 \quad \text { Yili } \\
\text { direct investment of } \\
2.022 \text { billion yuan }\end{array}$ & $\begin{array}{l}\begin{array}{l}\text { Constriction for } \\
\text { grassland } \\
\text { (people, 2003) }\end{array} \\
\end{array}$ \\
\hline Policy & $\begin{array}{l}\text { Water-saving } \\
\text { irrigation } \\
\text { technology }\end{array}$ & Xinjiang Corps & $\begin{array}{l}267000 \text { ha arable } \\
\text { land } 2001-2005\end{array}$ & $\begin{array}{l}\text { Irrigation techniques, } \\
\text { irrigation hose technology } \\
\text { (XJ daily, 2002) }\end{array}$ \\
\hline Plan & $\begin{array}{ll}\text { Shanshan } & \text { create } \\
\text { ecological } & \text { forest } \\
\text { planning } & \end{array}$ & $\begin{array}{l}\text { Japanese } \\
\text { fund }\end{array}$ & $\begin{array}{l}1.86 \text { million in } \\
2007,3 \text { years free } \\
\text { of charge into } 1,800 \\
\text { acres of forest }\end{array}$ & $\begin{array}{l}\text { Local ecological forest } \\
\text { construction (DB/OL, } \\
2004)\end{array}$ \\
\hline
\end{tabular}


Currently, land management is the responsibility of the Land and Resources Bureau of Land Management resources and mining, management of arable land and grassland Ministry of Agriculture, Bureau of Water Resources Management water and soil erosion, land management and environmental quality assessment and Environmental Protection Agency and Bureau of Forestry and forest management. Using many law enforcement agencies may not be a very efficient way for the effective law enforcement. "Desertification Law" stipulates that the State Forestry Administration act as desertification coordinator, while for the existing "Forestry Law", "Grassland Law", "Water and Soil Conservation Law", "Environmental Protection Law", "Water Law", "Land Management Law", "Meteorology Law", the division of responsibility is still valid.

That breaks the old pattern of national land management, and changes in the enforcement of the main provisions of the law, and will no doubt result in overlapping land management chaos. There will inevitably be a number of management organs of the same intent, but with different rules, so that the sand area farmers may not know what has caused obstacles to the sand management. In addition, these laws also effects power of the State Forestry Administration to a mere figurehead, with resulting failure of effective implementation of law, and will inevitably affecting the forestry, water conservancy, agriculture and other sectors in Xinjiang.

The $<$ Xinjiang Uygur Autonomous Region implemented the "PRC Forestry Law" that states $>$ Article I: "To protect, nurture and use of forest resources, accelerate forestation by planting the forest and soil conservation, climate regulation to improve the environment and enhance the role of forest products to meet the needs of community Socialist construction and people's living." "Forest resources and assets assessment management Interim Provisions " Article1, "To strengthen the management of forest resources and assets assessment, standardized assessment of forest resources and assets, safeguarding public interests and assets assessment for the legitimate rights and interests of the parties". This only provides for the protection of forests and forest soil, and not designed for various wild animals and plants depend on forest resources are not protected. "Grassland Law" Article states: "In order to strengthen the protection of grassland, management, development and rational use, protection and improvement of ecological environment, this Law is formulated,". But in the regulations of the land, the heavy economic compensation is made for land acquisition, but very low Eco-Environmental compensation. This serious violation of the harmonious development between man and nature values, also contrary to sustainable development. In addition, the main relationship between these legal provisions of the law is not clear, anti-desertification and protected the ecological environment on the main rights and obligations not provided for, thereby preventing and treating desertification legislative purpose of protecting the environment cannot be achieved.

With this administrative chaos with the existing legal documentations and responsibilities about protection of ecological environment in Xinjiang, no law enforcement and the administration agency acquire the full legal responsibility and ready to make the appropriate regulations. In term of the Xinjiang environmental legislation, from the point of view of any single department, there is no serious legislation powers and obligations of full reciprocity issues, therefore the law, justice and fairness cannot be reflected comprehensively. Existence of this problem is not very conducive to mobilizing the enthusiasm of the general population, limiting the management of natural resources, ecological environment and desertification control work in Xinjiang.

Under the anti-desertification environmental litigation system, 'any person' is liable for the violation of environmental law. It gets rid of the traditional litigation system, in which only the person who has the direct interest with the subject matter of litigation may sue as the plaintiff. It may dilute the impact factors of public interest. Thus, establishing legal qualification is the key to the anti-desertification environmental litigation.

However, in judicial practice the uncertainty of management body always leads to the irrationality of legal qualification, which violates the relevant provisions of Civil Procedure Law. For the qualification and scope of the plaintiff in environmental litigation system, academic community has different points of view. Some scholars believe that only the prosecutors on behalf of state power can bring public interest litigation. Some believe that all citizens, social groups and prosecutors can bring public interest litigation. The author believes that in an anti-desertification environmental litigation, the qualification of plaintiff should not be confined by the restriction of 'direct interest' in the traditional procedure law.

Since the environmental violation is indirect, the infringement often acts on the victim through environment rather than directly on the victim. Thus, it is very difficult for the traditional procedure law to regulate environmental violation. Moreover, since the environmental violation is extensive, the objective is often the majority of unspecified people or object in certain region. The individual victims always suffer because their damage is too small, and their prosecution cannot meet the legal requirements for the loss of property or substantial damage. They may also be scared by the high cost of litigation. Obviously, these conditions are 
extremely unfavourable for the environmental protection. As such, many countries have relaxed the standing to sue to comply with their sustainable development. Many common law countries have promoted group litigation system. In the cases of illegal exploitation of natural resources, citizens, legal persons or other organizations, in violation of state laws and regulations, exploit natural resources. It results in the damage or destruction of natural resources. Natural resources are the common property of all citizens, which affect the economic lifeline of country and the sustainable development of human society. Managing natural resources is not only the responsibility of country, but also the within power of each citizen. Thus, illegal exploitation of natural resources should be included in the case of anti-desertification environmental litigation.

\section{Discussions}

At present, Xinjiang anti-desertification legal litigation system is not comprehensive, leading to difficulties in filing the cases by citizens who really care about the public interest in preserving the environment and prosecuting the offenders. The plaintiff bears the burden of allocation of proof, as well as the cost of litigation, making it difficult currently to carry out the litigation proceeding against the offenders in Xinjiang. According to China's civil law, one who brings out the ligation proceeding must be the one "who has a direct interest". In other words, the environmental civil disputes must be personal or property rights of those directly affected by a civil wrong against another person. This is clearly very unfavourable for the civilian victims of the environment degradation, because most of the time they are affected by the environment abuses that are "indirect" and "invisible". Because of their large scope (affecting huge population, and cover wide range of damages) of the Public interest litigation cases, the courts are also reluctant in handling these cases, and consequently the judicial means are not uniform. In anti-desertification environmental litigation, the larger objective of civil litigation deals with the deterrent power of the respondent.

Countries generally believed that, although the government's implementation of monetary penalties is a very important tool but the citizen plaintiffs in environmental litigation are not entitled to request monetary damages. Similarly, China's "Environmental Protection Law" Article I: "liability and compensation disputes, according to request of the parties, by the environmental protection department or other administrative organs". According to the law to exercise environmental supervision and management of the department; the parties may accept the decision on treatment or may apply to the people's court. The parties may also directly refer to the people's court.

Administrative department of environmental protection has the advantage of dealing with environmental civil disputes. Environment, civil disputes often involve a lot of specialized legal and technical expertise. In this regard, the environmental protection administration departments will no doubt have a greater advantage than the Court. Even if the curt accept the environmental civil dispute, it cannot continue without the support of the environmental protection administration departments.

U.S. Federal Environmental Agency (EPA) policy on Civil Penalty requires that a request to impose financial penalties should be based on the illegal economic benefits obtained by the offender from the activities that has resulted to the environmental harm. The offence should be based on the degree of intent or negligence, the law-abiding state and solvency of the other factors taken into account. The courts in Xinjiang may have little interest in protecting the environment, because they may not have any such relevant provisions or regulations, and there is no specific environmental justice (protection) agencies, and no judges has made any specific judicial interpretation for the environmental protection in Xinjiang. For that reason the majority of courts Xinjiang cannot carry out the anti-desertification grass-roots civil trials, and therefore the ruling authority of the administrative department of environmental protection is far better than the mediation of views (as compare to the legislative courts in Xinjiang). In Anti-desertification environmental civil disputes the plaintiff has burden of proof, without the support from the executive branch of the environmental agency it is very difficult to win such cases. In addition, the reconciliation is also another important way in the United States during the civil litigation process for the court and the plaintiff; the defendant and the plaintiff may not have to continue with the litigation process as far as the court settlement and may settle the dispute on their own. If found guilty the offender undertake the legal obligation and may have to pay certain amount of fine to the state treasury. This is often the final settlement agreement and may result in the transfer payment to the plaintiff (Michael S. Greve, 1990).

Thus, in practice, the Xinjiang judicial administrative department of the environment in addition to general support for environmental litigation cases can also learn from foreign experience in civil litigation environment, civil penalties, settlement and other relief measures. Traditionally in the civil law the burden of proof, the civil burden of proof, follows the principle of "The one who advocates, the one who proof", therefore in most of such cases the burden of proof should lies on the plaintiff. However, in environmental litigation, the environmental damage and its consequences may be ill defined and therefore it may be extremely difficult for the plaintiff, due 
to the limited access of the plaintiff to information, and inadequate necessary professional knowledge and skills, to undertake this burden of proof. Therefore, in order to achieve the balanced approach, many countries practices no-fault liability in the implementation of the environmental case and in the burden of proof, the main evidence is provided by the defendant but not plaintiff. Such as in the United States, "Michigan Environmental Protection Act," Article III, the plaintiff need only to provides prima facie evidence that vandals have been or is likely to have disruptive behaviour; and the burden of proof is complete. If the defendant has denied the destruction, or deny their behaviour will cause damage as a result, they must provide evidence to the contrary (Tong Ling, 2007). For these reasons, in Xinjiang anti-desertification environmental public interest litigation, the principle of civil burden of proof must be redefined; public interest litigation in civil environment cases require the plaintiff's prima facie evidence of destructive behaviour, which can support its request. The fact is that the existence of damage whether is there any cause and effect relationship between vandalism and the damage, if so the burden of proof is reserves to defendant.

Article 4 of Law of the People's Republic of China on Prevention and Control of Desertification provides that 'the state, in desertified regions, establishes a responsibility, appraisal, reward and punishment system with respect to the targets set to government leaders during their term of office; people's governments at or above the county level located in desertified regions shall report to the people's congresses and their standing committees at the corresponding level on prevention and control of desertification.' Article 5 of Administrative Provisions of Xinjiang Uygur Autonomous Region on Prevention and Control of Desertification provides that 'regional anti-desertification coordination group is responsible for the anti-desertification in Xinjiang Uygur Autonomous Region; desertification centralized state, city and county should also establish appropriate coordination group and joint meeting system to solve the issues related to anti-desertification'. This Article is obviously aimed to advocate government engaging in anti-desertification work. However, it does not involve an administrative target assessment system in relation to anti-desertification. Accordingly it may not essentially enhance the administrative responsibility and supervise the anti-desertification work of government.

To establish target responsibility system on anti-desertification, each session of the government must specify and announce its mission statement for anti-desertification. The main purpose is to enable the public to know the actions taken by the government and the ultimate effects resulted from such actions, and to further change the information asymmetry between government and public. When the public found any negligence of government, they may raise objections or directly bring an administrative lawsuit before the court. The court shall grant a judicial proposal to the higher administrative authority to urge the government to fulfil its obligations.

In addition, Xinjiang currently has a variety of remedy measures in relation to administrative enforcement for anti-desertification, e.g. environmental administrative licensing, environmental administrative enforcement, environmental administrative penalty, administrative reconsideration and administrative litigation. In accordance with the provisions of Administrative License Law of the People's Republic of China, after reviewing the administrative license application, if the environmental administrative authorities found that the administrative licensing matters directly endanger the vital interests of others, it shall inform them immediately. Applicant and other involved parties have the right to make a statement and defence. Moreover, in accordance with the provisions of Administrative Punishment Law of Xinjiang Uygur Autonomous Region on Separation of Collection and Payment Methods, environmental sector may, within its statutory purview, entrust environmental monitoring agencies to impose administrative penalties. Even if the involved parties appeal against administrative penalties, apply for an administrative reconsideration or bring an administrative litigation, they are still given administrative punishment. If the involved parties are overdue to apply for an administrative reconsideration, bring an administrative litigation or refuse to pay penalties, the corresponding environmental sector may apply to court for enforcement.

Anti-desertification is the most important part of ecological construction. Solving desertification problem can fundamentally improve the living conditions of the rural areas in Xinjiang to push the local economic development. Government plays a dominant role in the anti-desertification work. Nevertheless, the government is made of individuals with various independent minds. The government actions thereby may not always be rational, e.g. the local government sometimes may abuse its power to sacrifice the ecological environment for short-term economic interests.

\section{Acknowledgment}

We would like to thank Dr. Lui Kai from Faculty of Law, National University of Malaysia for his proof reading. 


\section{References}

Backgrounder: Xinjiang Uygur Autonomous Region. Retrieved from http://news.xinhuanet.com/english/2009-07/07/content_11668365.htm

Ban, P. G. (n. d.). The Atlas of World Archeology (pp. 134-135). New York: Check mark Books.

China and strive to from the "sand pressing back" to "people to force the sand back." (2004). Chongqing Publishing House. Retrieved from http://www.fmprc.gov.cn/ce/cedk/ch

Corps built the country's largest water-saving irrigation demonstration area. (2003). Retrieved from http://serve.xj169.net/news

Hotan to spend 1.3 billion to combat desertification ecological construction project to start. (November, 22, 2002). Xinjiang Daily. Retrieved from http://www.xjdaily.com.cn

Investment in ecological construction in Xinjiang can enjoy preferential policies. (2003). Retrieved from http://serve.xj169.net/news/

Kram, M., Bedford, C., Durnin, M., Luo, Y., Rokpelnis, K., Roth, B., \& Zhao, X. (2012). Protecting China's biodiversity. Exploration of Nature, 15, 1-5.

Leiss, W. (1993). Natural control theory. (Trans.: Yue Changling). Retrieved from http://serve.xj169.net/news

Liu, X. P., \& Han, T. K. (2005). Analysis of the ecological environment in Xinjiang Oasis. Arid Land Resources and Environment, (1), 22.

Menon, S., Hansen, J., Nazarenko, L., \& Luo, Y. (2002). Climate effects of black carbon aerosols in China and India. Science, 297, 2250-2253. http://dx.doi.org/10.1126/science.1075159

Michael, S. G. (1990). The Private Enforcement of Environmental Law. Tul. L. Rev., 339(7), 83.

Shi, Y. C. (2005). The ultimate aim of environmental legislation - On the Value of Sustainable Development. Northwest University, (1), 129-130

Sun, J. M., \& Lou, T. S. (2006). The Age of the Taklimakan Desert. Science, 312(16), 1621. http://dx.doi.org/10.1126/science.1124616

Taklamakan Desert. Encyclopedia Britannica. Retrieved August 11, 2007.

Tarim Desert Highway shelterbelt ecological projects started. (2003). Retrieved from http://serve.xj169.net/news/

The state has invested 2 billion yuan for the construction of Yili grassland. (2003). Retrieved from http://serve.xj169.net/news/

The World's Largest Deser. Retrieved August 22, 2007.

Tong, L. (2007). On the Construction of Environmental Public Interest Litigation. Changchun: Jilin University, 4.

Wang, J. (2000). Environmental Law held ideas and values - the legislative inten. Law Press, 11.

Zhang, L. (2004). The ecological environment of the Western Development Compensation Legislation. Beijing: China University of Political Science, 5.

Zhou. (2003). Attention from the strategic national ecological safety. China Information.

\section{Copyrights}

Copyright for this article is retained by the author(s), with first publication rights granted to the journal.

This is an open-access article distributed under the terms and conditions of the Creative Commons Attribution license (http://creativecommons.org/licenses/by/3.0/). 